Univerzitet u Beogradu
Poljoprivredni fakultet
Institut za poljoprivrednu tehniku
Naučni časopis
POLJOPRIVREDNA TEHNIKA
Godina XLV
Broj 3, 2020.
Strane: $1-14$

\title{
EFFECT OF FREEZE DRYING ON QUALITIES OF FRESH COW MILK AND SOY CHEESES
}

\author{
Tosin Paul $^{* 1}$, Bolanle Adejumo ${ }^{2}$, Nnaemeka Nwakuba ${ }^{1}$, Augustine Igbozulike ${ }^{1}$ \\ ${ }^{I}$ Department of Agricultural and Bioresources, College of Engineering and Engineering \\ Technology, Michael Okpara University of Agriculture, Umudike, Nigeria. \\ ${ }^{2}$ Department of Agricultural and Bioresources, Federal University of Technology, \\ Minna, Niger State, Nigeria.
}

\begin{abstract}
The effect of freeze drying on the qualities of fresh cow milk and soy milk cheeses was investigated, with a view to preserve and present them in a more stable and portable form. The cow milk cheese and soy milk cheese used were freshly prepared with dimension of $2 \times 3 \mathrm{~cm}$ and $0.2 \mathrm{~cm}$ thickness. The cow milk and soy cheese were divided into 6 portions of $100 \mathrm{~g}$ each The initial properties of the cheeses samples been determined using a portion of $100 \mathrm{~g}$ each the remaining $500 \mathrm{~g}$ were freeze dried. The nutritional, microbial and sensory qualities of the freeze dried cheeses were determined using standard methods. Results showed that freshly prepared cow milk cheese contains $54.02 \%$ moisture, $20.34 \%$ protein, $6.40 \%$ ash, $18.11 \%$ fat and $4.25 \%$ carbohydrate, $3.52 \mathrm{mg} / 100 \mathrm{~g}$ sodium, $7.02 \mathrm{mg} / 100 \mathrm{~g}$ potassium, $5.22 \mathrm{mg} / 100 \mathrm{~g}$ magnesium, $6.32 \mathrm{mg} / 100 \mathrm{~g}$ iron, $11.12 \mathrm{mg} / 100 \mathrm{~g}$ calcium, $3 \times 10^{3} \mathrm{cfu} / \mathrm{g}$ bacteria and $2.54 \times 10^{6} \mathrm{cfu} / \mathrm{g}$ fungi whereas freshly prepared soy cheese contains $50.89 \%$ moisture, $22.05 \%$ protein, $6.31 \%$ Ash, $19.02 \%$ fat and $4.06 \%$ carbohydrate, $3.52 \mathrm{mg} / 100 \mathrm{~g}$ sodium, $7.04 \mathrm{mg} / 100 \mathrm{~g}$ potassium, $5.14 \mathrm{mg} / 100 \mathrm{~g}$ magnesium, $6.20 \mathrm{mg} / 100 \mathrm{~g}$ iron, $10.76 \mathrm{mg} / 100 \mathrm{~g}$ calcium, $2.76 \times 10^{3} \mathrm{cfu} / \mathrm{g}$ bacteria and $2.60 \times 10^{6} \mathrm{cfu} / \mathrm{g}$ fungi. The moisture and fat contents of the freeze dried cow milk and soybean milk decreased significantly ( $\mathrm{P}<0.05$ ) from $54.02 \%$ to $4.28 \%$, $18.11 \%$ to $4.05 \%$ and $50.89 \%$ to $4.19 \%, 19.02 \%$ to $4.30 \%$ respectively. Freeze drying significantly decreased the bacteria and fungi contents of fresh cheeses; it decreased from $3 \times 10^{3} \mathrm{cfu} / \mathrm{g}$ to $2.72 \times 10^{3} \mathrm{cfu} / \mathrm{g}, 2.54 \times 10^{6} \mathrm{cfu} / \mathrm{g}$ to $2.35 \times 10^{6} \mathrm{cfu} / \mathrm{g}$, and $2.76 \mathrm{x}$ $10^{3} \mathrm{cfu} / \mathrm{g}$ to $2.54 \times 10^{3} \mathrm{cfu} / \mathrm{g}, 2.60 \times 10^{6} \mathrm{cfu} / \mathrm{g}$ to $2.38 \times 10^{6} \mathrm{cfu} / \mathrm{g}$ for cow milk and soy milk cheese respectively.
\end{abstract}

\footnotetext{
*Corresponding author. E-mail: ptosin106@gmail.com
} 
The carbohydrate, protein, ash content, calcium, sodium, magnesium, taste, appearance, flavour, acceptability of the cow milk cheeses increased significantly $(\mathrm{P}<$ 0.05) when freeze dried. Decreases in moisture content, fat and microbial counts of cheeses would enhance its stability and shelf life if properly packaged.

Keywords: Cheese, freeze drying, nutritional qualities, microbial qualities, sensory qualities.

\section{INTRODUCTION}

Cheese is a product made from the curd obtained from milk by coagulating the casein with the help of rennet or similar enzymes in the presence of lactic acid microorganism [1]. Cheese is the fresh or ripened product obtained after coagulation and whey separation of milk, cream or partly skimmed milk, buttermilk or a mixture of these products, it can also be made from the milk of cows, sheep, goats and camels or mixture of two of these [2]. The objective of cheese making is to obtain the optimum cheese composition with respect to moisture, acidity, fat, protein and minerals. Cheese provides a high concentration of nutrients relative to its energy content. The nutritional composition of cheese depends on the type of milk used and the manufacturing and ripening procedures [3].

Each type of milk imparts the characteristics quality of cheese made from it and the resulting cheese will differ in its proprieties, body texture, and flavor [4]. There are great varieties of cheese, some are perishable and must be consumed within few days while other can be stored for years [2]. White cheese is the only type of cheese available to the public in large quantities in most Nigerian markets. Warsama et al. [5] reported that Nigerian white soft cheese contained $47.8 \%$ total solids, $14.0 \%$ fat, $15.9 \%$ protein and $6.2 \%$ ash.

Natural cheese should be processed at acceptable temperatures to ensure good consistenc $\mathrm{y}$, as a high temperature contributes to moisture evaporation and development of undesir able bacteria and other faults [1].

The macro and micro-nutrients contained within foods all show varying degrees of stability when foods are stored or processed. One of the greatest challenges facing food scientists/technologists in Nigeria today is the upgrading of the traditional technologies of cheese processing and preservation [6]. The traditional methods of cheese processing and preservation in Nigeria remain at the empirical level. The processes are laborious, time consuming and invariably the quality of the products require substantial improvements [7]. Handling and preservation of cheese is a problem which causes excess losses and a short shelf life on account of its high moisture content, which is responsible for the rapid deterioration. Cheese processing and the various preservative methods have inevitable consequences on the nutritional value of cheese. The macro and micro nutrients contained within the cheese all show varying degrees of stability when cheese are processed and stored [2].

Biochemistry of fresh cow milk and soy cheeses shows quite similar compounds including proteins, lipids, carbohydrates, esters, alcohols, aldehydes and minerals [8]. 
The physiochemical changes caused by processing of soy cheese are quite similar to those of cow milk cheese, e.g. proteolysis, i.e. formation of amino acids from larger protein molecules, lipolysis, i.e. conversion of fats into smaller units called fatty acids, and production of aldehydes, alcohols, esters, etc. [9]. The processing steps like coagulation, pressing, cutting, salting, ripening, etc. are almost similar, with some exceptions due to the use of different kind of cultures [10].

The main difference between animal milk and soy milk is that soy milk does not contain lactose and casein, but this does not affect cheese making because soy sugars can serve the role of lactose, while soy milk proteins have the same role like milk proteins [11]. Owing to the worldwide shortage of food, attempts have been made to find alternative sources of protein, particularly for the nations where malnutrition exists. Soybeans particularly are plentiful, relatively inexpensive and rich in protein. Soy-based foods may provide additional benefits for the consumer due to their hypolipidemic, anticholesterolemic, anti-atherogenic properties and reduced allergenicity. It provides an alternative source of protein for people who are allergic to milk protein [2], [8].

Soy cheese and cow milk cheese get spoilt or rancid after some days; therefore there is a need to extend the shelf life by destroying or inhibiting micro-organisms and slowing down enzymes. One of the ways by which cheese can be preserved is by freeze drying method, and this method can transform the cheeses into forms that have longer shelf life rather than keeping them in fresh forms which are perishable [12]. Because of the absence of liquid water and the low temperature (approx. $20^{\circ} \mathrm{C}$ ) used during freeze drying operation, most of deterioration and microbiological reaction are stopped [13]. Due to lack of liquid water and the low temperature (approx. $20{ }^{\circ} \mathrm{C}$ ) used during the freeze drying process, the bulk of degradation and microbiological reaction was halted [13]. For freeze dried products shrinkages are removed, minimal degradation of flavour, aroma, vitamins, and near-perfect preservation outcomes are produced. The objective of this work is to determine the effect of freeze drying on the qualities of fresh cow milk and soy milk cheeses.

\section{MATERIAL AND METHODS}

One thousand five hundred grams $(1500 \mathrm{~g})$ of soy beans and three litres (31) of fresh cow milk was purchased at Kure Market Minna Niger State. Soy cheese and cow milk cheese used for this study was produced in the Crop Processing and Storage Laboratory of the Department of Agricultural and Bioresources Engineering, Federal University of Technology, Minna, Niger State, Nigeria.

\section{Reagents and Instruments}

The following reagents were used during freeze drying, packaging and analysis of both cheeses.

\section{Reagents}

Distilled water, petroleum ether, boric acid, hydrochloric acid, mixed indicator, nhexane, nitric acid, potassium hydroxide, polyethylene bag. 


\section{Instrument and Apparatus}

The instrument used for this research study are drying racks, sealing machine, lyophilizer, petri-dishes, desiccators, filter paper, electronic weighing balance, soxhlet apparatus, digestion block, pipette, conical flask, beakers, muffle furnace, flame photometer, atomic absorption, spectrophotometer, funnel, thistle funnel, measuring cylinder, kjeldahl apparatus, metallic tray.

\section{Methodology}

Fresh whole milk was used as prescribed by Amano [14] in the production of cow milk cheese. The fat content of the milk was reduced by keeping the milk settled for about one hour then the top layer was skimmed off (high fat milk or cream). The milk was heated to about $85^{\circ} \mathrm{C}$ to destroy most of the bacteria present and also to increase yield through precipitation of the whey proteins [15], Lemon juice (Coagulant) was diluted with an equal quantity of clean fresh water so that the lemon juice can be distributed uniformly. About $30 \mathrm{ml}$ of lemon juice per litre of milk was added and stirred while carefully adding the lemon juice [9].

The curd precipitated almost immediately. Stirring continued for about three minutes after adding the lemon juice and then the curd was allowed to settle for 15 minutes. The curd was separated from the whey by draining through a muslin (cheese) cloth. While draining the whey, the curd was stirred to prevent excess matting [15]. Salt was added to the curd at a rate of about $4 \mathrm{~g}$ for every $100 \mathrm{~g}$ of curd and mixed properly. The quantity of salt may be varied to cater for the consumers taste preferences. The curd was transferred to a mould (container) lined with muslin (cheese) cloth. The curd was wrapped with the muslin (cheese) cloth and a wooden follower was fitted neatly inside the mould to enable the curd to be pressed [7]. The curd was pressed by placing metal weights on top of the wooden follower. The cheese was removed from the mould and then cut into sizes of $2 \times 3 \mathrm{~cm}$ dimension and thickness of $0.2 \mathrm{~cm}$. It was taken to the laboratory and freeze dried. The freeze dried samples were then packaged in the different packaging materials for further analysis.

The production of the soy cheese from soy beans was carried out as prescribed by Connor [16], 2003. About $1500 \mathrm{~g}$ of properly cleaned soy beans was soaked in water for 12-14 hours after which the soybeans was dehulled, grinded and mixed with water. A sieve was used to separate the milk from the chaff in the mixture [9]. The milk was boiled (pasteurizes) and allowed to cool while the coagulant (Lemon juice) was added to the milk to form curd. The curd was wrapped with the muslin (cheese) cloth and pressed in a mould to remove the water present in the curd [17]. The hardened cheese was then cut into sizes of $2 \times 3 \mathrm{~cm}$ dimension and thickness of $0.2 \mathrm{~cm}$. The soy cheese was then taken to the laboratory and freeze dried. The freeze dried samples were then taken for further analysis.

\section{Nutritional Analysis}

The nutritional composition of samples A (cow milk cheese) and B (soy milk cheese) was determined according to the method described by the Association of Official Analytical Chemists [18]. The procedures for the determination of the nutritional properties of cow milk and soy cheese are as follows: 


\section{Determination of moisture content}

The petri-dish was washed thoroughly and dried in an oven for few seconds and removed, cooled to room temperature in the desiccators. The petri-dishes were weighed using the electric weighing balance and their corresponding weight was recorded as $\mathrm{W}_{1}$, Five grammes $(5 \mathrm{~g})$ of sample was measured and added to the petri-dishes, the weight of the petri-dish and the sample was recorded as $\mathrm{W}_{2}$. The petri-dishes (containing their respective samples) was dried in an oven at $105^{\circ} \mathrm{C}$ until constant weight [18]. After the drying time elapsed, the samples was removed from the oven and cooled in the desiccators to room temperature, while they are reweighted one after another and the new weight (Weight of petri-dishes +dried sample) was recorded as $\mathrm{W}_{3}$. The moisture content or percentage moisture (dry basis) for each sample was then calculated as:

$$
\begin{aligned}
& \text { Moisture content }=\frac{\mathrm{W}_{2}-\mathrm{W}_{3}}{\mathrm{~W}_{2}-\mathrm{W}_{1}} * 100 \\
& \text { Where: } \\
& \mathrm{W}_{1}=\text { Weight of petri-dish, } \mathrm{g} . \\
& \mathrm{W}_{2}=\text { Weight of petri-dish and initial sample, } \mathrm{g} . \\
& \mathrm{W}_{3}=\text { Weight of petri-dish and dried sample, } \mathrm{g} .
\end{aligned}
$$

\section{Determination of Ash content}

Three porcelain cubicles are thoroughly washed, heated, cooled in desiccators and weighed using the electronic weighing balance and the cubicles weight were recorded as $\mathrm{W}_{1}$. Two grams $(2 \mathrm{~g})$ of each sample were added to its corresponding crucibles, the new weight of crucible and the samples was recorded as $\mathrm{W}_{2}$. After this, the samples were heated in a muffle furnace at $550^{\circ} \mathrm{C}$ for two hours to ash. At the end of the ashing period the samples was light grey in colour [19]. Removing the sample with the aid of tongs, the samples was cool in desiccator for some minutes prior to weighing. After cooling, the samples was weighed and the weight was recorded as $\mathrm{W}_{3}$. The percentage ash for each sample was then calculated as:

$$
\begin{aligned}
& \% \text { Ash }(\text { dry basis })=\frac{\text { weight of Ash }}{\text { weight of original cheese }} \times 100 \% \\
& \% \text { Ash }=\frac{\mathrm{W} 3-\mathrm{W} 1}{\mathrm{~W} 2-\mathrm{W} 1} \times 100 \%
\end{aligned}
$$

\section{Determination of fat content}

The fat content was determined by the procedure of [18]. Three $250 \mathrm{ml}$ beakers was thoroughly washed, heated and cooled in desiccators. Three filter papers were selected and their corresponding weights was recorded as $\mathrm{W}_{1}$. Two grams $(2 \mathrm{~g})$ of each sample was measured into each of its corresponding filter paper and the new weight recorded as $\mathrm{W}_{2}$ approximately. The filter paper with their respective sample in them was then neatly folded and closed in a manner that the sample was perfectly locked in them. Each of the dried beakers was filled with about $300 \mathrm{ml}$ of petroleum ether boiling point $40-60^{\circ} \mathrm{C}$.

The Soxhlet apparatus was then assembled, each filter was placed in each extraction chamber of the entire Soxhlet set up, and the top controlling the continuous flows of water into the condenser was open. 
The power was on and the heating temperature was regulated to $50^{\circ} \mathrm{C}$ until the petroleum ether in the boiling flask started to boil, then the heating temperature was regulated down to $30^{\circ} \mathrm{C}$. The apparatus was allowed to reflux for 6hours, at the end of the stipulated time (6 hours). The filter paper was removed carefully and taken to be dried in an oven for an hour at $105^{\circ} \mathrm{C}$ after which it was then cooled in a desiccator for some minutes, the new weights of the filter paper along with their contents are then measured again using the electric weighing balance and the weights measured was recorded as $\mathrm{W}_{3}$. Finally, the percentage of fat was then calculated using the formula:

$$
\% \text { of Fat }=\frac{\text { weight of Fat }(\mathbf{W} 3-\mathbf{W} 1)}{\text { original Sample }(\mathbf{W} 2-\mathbf{W} 1)} \times 100
$$

\section{Determination of crude protein content}

About $0.5 \mathrm{~g}$ of each sample was weighed into three kjeldahl flask; $20 \mathrm{~cm}^{3}$ conical flask, $\mathrm{H}_{2} \mathrm{SO}_{4}$, and $0.98 \mathrm{~g}$ of selenium tablet was added to each sample in its tube to act as a catalyst. The mixture was then heated at a low temperature for about 15 minutes and then increased to a higher temperature for 30minutes and then at extra-high temperature until the sample was digested; at this stage, the solution was clear and colourless. The samples are then allowed to cool for a while. This was followed by the distillation of each sample using a kjeldahl distillation setup. $5 \mathrm{~mm}$ of $2 \%$ Boric acid was prepared and poured into a $100 \mathrm{ml}$ conical flask (as a receiving flask), 3 drops of mix indicator (bromocresol green and methyl) was added to the receiving flasks.

The receiving flask was then placed under a condenser such that the tip of the condenser tube was below the surface of the boric acid. $5 \mathrm{ml}$ of the digested sample was then pipette into the body of the body of the apparatus via the small funnel aperture and washed down with distilled water followed by $5 \mathrm{ml}$ of $60 \% \mathrm{NaOH}$ solution. Steam was passed continuously through the set up for 7 minutes to collect enough ammonium sulphate after which the receiving was removed and the tip of the condenser washed down into the flask. The condenser water was also removed, the distillate or solution in the receiving flask was then titrated using $0.05 \mathrm{~m}$ hydrochloric acid and the titer value was recorded as $T_{1}$. The percentage Nitrogen was then calculated as:

$$
\% \text { of Nitrogen }=\frac{\mathbf{T} \times \mathbf{M} \mathbf{X} \mathbf{0 . 0 1 4} \mathbf{X V}}{\mathbf{W}} \times 100 \%
$$

Molarity of acid $=\mathrm{M}$

Where $\mathrm{V}=10$

Control Titre $=\mathrm{T}$

$\%$ of crude protein $=\%$ of Nitrogen $\mathrm{x}$ conversion factor Protein conversion factor $=6.23$

\section{Carbohydrate}

$\%$ of carbohydrate $=100 \%-(\%$ of fat $+\%$ of crude protein $+\%$ of Ash $+\%$ of crude fibre). 


\section{Determination of potassium concentration}

About $0.5 \mathrm{~g}$ of the sample was first digested with $500 \mathrm{ml}$ of acid mixture $(650 \mathrm{ml}$ conc., $\mathrm{HNO}_{2}, 80 \mathrm{ml}$ per chloric acid; $20 \mathrm{ml}$ conc. $\mathrm{H}_{2} \mathrm{SO}_{4}$ ) and the sample was then heated until clear digestions was obtained and allowed to cool down. The digested sample was then diluted with $500 \mathrm{ml}$ distilled water, a stock solution containing $100 \mathrm{mg} / \mathrm{ml}$ of $\mathrm{K}^{+}$ions are prepared to dissolve $1.907 \mathrm{~g}$ of $\mathrm{KCl}$ in water. The potassium emissions measured in air acetylene flame. A calibration curve of potassium emission against concentration was drawn and reading was noted and recorded.

\section{Determination of magnesium concentration}

Five $m l(5 \mathrm{ml})$ aliquot of the sample solution was measured into a $100 \mathrm{ml}$ conical flask. $5 \mathrm{ml}$ ammonium chloride-ammonium hydroxide buffer solution was then added followed by $1 \mathrm{ml}$ of triethanolamine. Three drops of $10 \% \mathrm{KCN}$ solution and few drops of EBT indicator solution was then added. The content in the flask was then thoroughly mixed by shaking and then titrated with 0.02 NEDTA solutions from a red to blue end point. Magnesium concentrations were then calculated.

\section{Determination of iron concentration}

Aliquots of standard sample and blank pipette into tubes and absorbance measured at $248 \mathrm{~nm}$ using air-acetylene flame. Calibration curve of absorbance was then drawn against the concentration of iron to determine the iron concentration.

\section{Sensory Evaluation of Freeze dried Cow milk and Soy Cheese}

Ten panelists who are familiar with the cow milk cheese and soy cheese were used for the sensory evaluation. Evaluations are made on a nine point hedonic scale with 9 indicating like extremely, 6 indicating like, 3 indicating dislike and 1 indicating dislike extremely. The fresh and freeze dried samples of cow milk and soy cheese were checked for colour, flavour, texture and overall acceptability.

\section{Microbial Qualities Determination}

The microbial qualities of the fresh and freeze dried samples of cow milk and soy cheese were determined using standard methods as prescribed by Compendium of Methods for the Microbiological Examination of Foods [20] and Bacteriological Analytical Manual [21].

\section{Determination of bacterial count in Cheese}

For each dilution to be plated, aseptically $1 \mathrm{ml}$ sample suspension was transferred to 3 plates of Baird-parker agar, distributing $1 \mathrm{ml}$ of inoculum equitably to 3 plates. Inoculum was spread over the surface of the agar plate using sterile bent glass streaking rod. The plates are kept in upright position until inoculum was absorbed by agar (about 10minutes) on properly dried plates.

The plates were inverted and incubated for 45 hours at $35^{\circ} \mathrm{C}$. Plates containing 20-200 colonies were selected. 
Colonies with typical appearance of bacterial are circular, smooth, convex, moist, $2-3 \mathrm{~mm}$ in diameter on uncrowded plates, gray (jet black) frequently with light coloured (off white) margin. Colonies have gummy consistency when touched with inoculating needle.

\section{Determination of fungi count in cheese}

The sample dilution containing fungi was placed in a kjeldahl flask. An alcoholic solution was used as indicator. Sufficient water was added to bring the total volume to $100 \mathrm{cc}$. The flask was connected to the condenser and the suction started. The mixture was brought to boiling, then the $\mathrm{MNO}_{2}$ was added but only after the vapours are condensing in the reflux condenser. The oxidizing agent was added drop by drop at a rate of not more than 1 per second until an excess has accumulated in the flask. When colloidal $\mathrm{MNO}_{2}$ was used, an actual excess was present for at least 10minutes. The addition of the oxidizing agent was up to 10 minutes. This excess in turn was removed by one drop of $0.1 \mathrm{~N}$ of thiosulphate solution. The end point was finally adjusted with the dilute iodine solution in such a manner that one drop of this dilute iodine solution produces a clearly discernable change, but not a deep blue in the colorless solution.

\section{Statistical Analysis}

All experiments were carried out in three replicate. Data obtained was analyzed statistically using SPSS 20.0 statistical package to determine the analysis of variance (ANOVA) and the Duncan multiple range test to separate the means. Time series regression analysis was used to develop a model to predict the effect of packaging materials and storage duration on selected nutritional, microbial and sensory qualities.

The freshly produced sliced soy and cow milk cheese used for the experiment are as shown in plate I and II while the freeze dried soy and cow milk cheese are shown in plate III and IV.

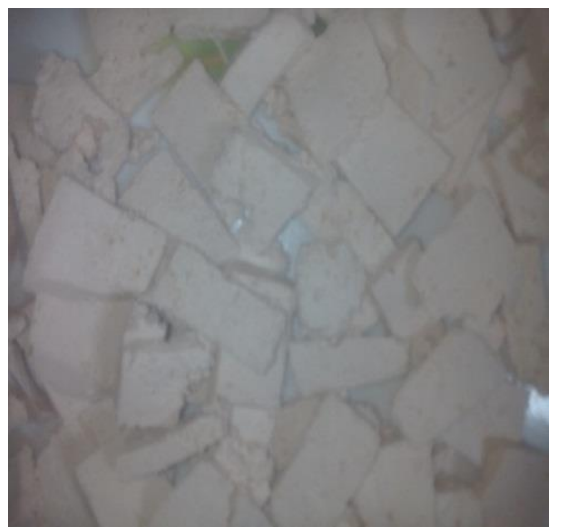

Plate I. fresh sliced soy cheese

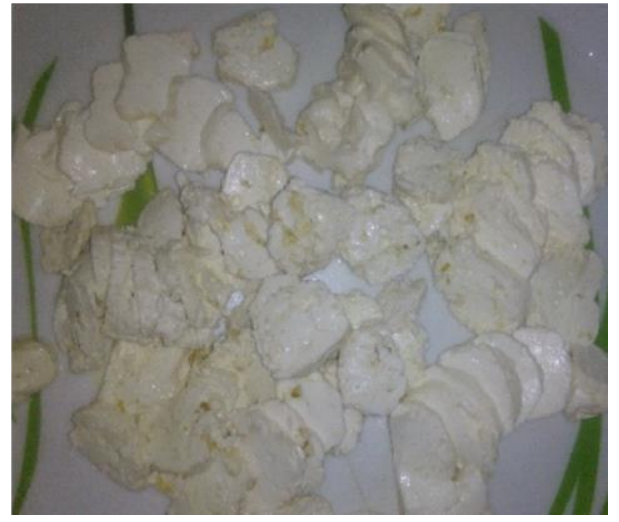

Plate II. Fresh sliced cow milk cheese 


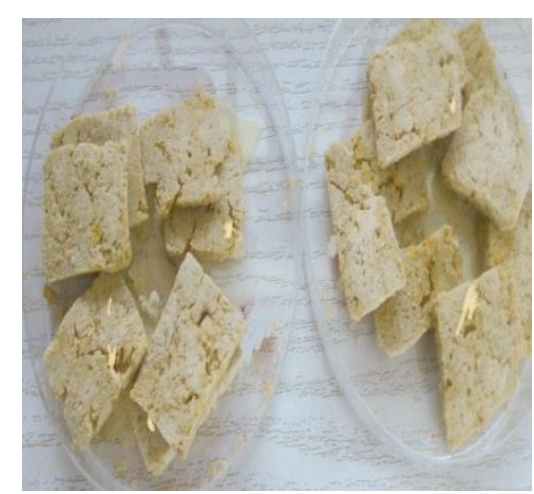

Plate III. Samples of freeze dried soy cheese

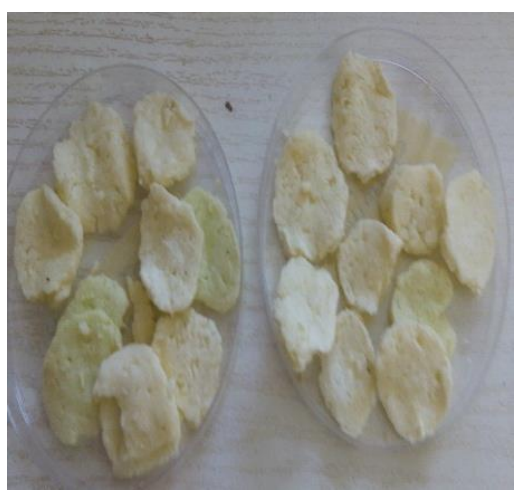

Plate IV. Samples of freeze dried cow milk Cheese.

\section{RESULTS AND DISCUSSION}

\section{The Nutritional, Microbial and Sensory Qualities of Fresh Cow Milk and Soy Milk Cheeses}

The results of the nutritional, microbial and sensory qualities of fresh cow milk and soy cheese are as presented in Table 1.

Table 1. Nutritional, microbial and sensory qualities of fresh cow milk and soy milk cheeses.

\begin{tabular}{lcc}
\hline \multicolumn{1}{c}{ Qualities } & Fresh Cow Milk Cheese & Fresh Soy Cheese \\
\hline Moisture Content $(\%)$ & $54.02 \pm 0.01$ & $50.89 \pm 0.12$ \\
Ash $(\%)$ & $6.40 \pm 0.32$ & $6.31 \pm 0.31$ \\
Protein $(\%)$ & $20.34 \pm 0.50$ & $22.05 \pm 0.02$ \\
Fat $(\%)$ & $18.11 \pm 0.06$ & $19.02 \pm 0.58$ \\
$\mathrm{CHO}(\%)$ & $4.25 \pm 0.20$ & $4.06 \pm 0.10$ \\
$\mathrm{~K}(\mathrm{Mg} / \mathrm{lOOg})$ & $7.02 \pm 0.03$ & $7.04 \pm 0.04$ \\
$\mathrm{Mg}(\mathrm{Mg} / \mathrm{lOOg})$ & $5.22 \pm 0.11$ & $5.14 \pm 0.14$ \\
$\mathrm{Fe}(\mathrm{Mg} / \mathrm{lOOg})$ & $6.32 \pm 0.12$ & $6.20 \pm 0.32$ \\
$\mathrm{Ca}(\mathrm{Mg} / \mathrm{lOOg})$ & $11.12 \pm 0.40$ & $10.76 \pm 0.60$ \\
Na $(\mathrm{Mg} / 100 \mathrm{~g})$ & $3.30 \pm 0.60$ & $3.52 \pm 0.85$ \\
Bacterial $(\mathrm{CFU} / \mathrm{g})$ & $3.00 \times 10^{3} \pm 0.01$ & $2.76 \times 10^{3} \pm 0.02$ \\
Fungi $(\mathrm{CFU} / \mathrm{g})$ & $2.54 x 10^{6} \pm 0.05$ & $2.60 x 10^{6} \pm 0.10$ \\
Colour & $7.00 \pm 0.05$ & $7.10 \pm 0.02$ \\
Aroma & $6.50 \pm 0.01$ & $5.40 \pm 0.01$ \\
Taste & $6.50 \pm 0.70$ & $7.00 \pm 0.05$ \\
Appearance & $6.10 \pm 0.01$ & $6.50 \pm 0.02$ \\
Overall Acceptability & $7.00 \pm 0.05$ & $7.20 \pm 0.01$ \\
\hline
\end{tabular}

The results showed that fresh cow milk cheese and fresh soy cheese contain $54.02 \%$ and $50.89 \%$ moisture respectively, this is similar to previous report by [2], who obtained $53.10 \%$ moisture for cow milk cheese and $50.25 \%$ moisture for soy cheese. 
The fresh cow milk cheese contains $6.40 \%$ ash, $20.34 \%$ protein and $18.11 \%$ fat while the fresh soy cheese contains $6.31 \%$ ash, $22.05 \%$ protein and $19.02 \%$ fat (Table 1 ).

The result of the mineral composition of the fresh cow milk cheese showed that the value for the sodium, potassium, magnesium, iron and calcium content are $3.30 \mathrm{mg} / 100 \mathrm{~g}$, $7.0 \mathrm{mg} / 100 \mathrm{~g}, 5.22 \mathrm{mg} / 100 \mathrm{~g}, 6.38 \mathrm{mg} / 100 \mathrm{~g}$ and $11.12 \mathrm{mg} / 100 \mathrm{~g}$ respectively. Sodium, potassium, magnesium, iron and calcium content of fresh soy cheese are $3.52 \mathrm{mg} / 100 \mathrm{~g}$, $7.04 \mathrm{mg} / 100 \mathrm{~g}, 5.14 \mathrm{mg} / 100 \mathrm{~g}, 6.20 \mathrm{mg} / 100 \mathrm{~g}$ and $10.76 \mathrm{mg} / 100 \mathrm{~g}$ respectively (Table 1 ). The fresh cow milk cheese contains $3.0 \times 10^{3} \mathrm{CFU} / \mathrm{g}$ bacteria count and $2.54 \times 10^{6}$ $\mathrm{CFU} / \mathrm{g}$ fungi count while fresh soy cheese contains $2.76 \times 10^{3} \mathrm{CFU} / \mathrm{g}$ bacteria count and $2.60 \times 10^{6} \mathrm{CFU} / \mathrm{g}$ of fungi count (Table 1 ). This is similar to bacteria and fungi counts in cheese which is reported to $3.2 \times 10^{3} \mathrm{CFU} / \mathrm{g}$ and $2.63 \times 10^{6} \mathrm{CFU} / \mathrm{g}$ respectively for fresh cow milk cheese by Adetunji and Babalobi [7]. The fresh cow milk and soy cheeses sensory properties are 7.00 and 7.10 colour, 6.50 and 5.40 aroma, 6.50 and 7.00 taste, 6.10 and 6.50 appearance, 7.00 and 7.20 overall acceptability respectively (Table 1). Similar result has been reported for dairy products by Lee and Castle [22].

Nutritional composition of freeze dried cow milk and soy milk cheeses

The results of the effect of freeze drying on the nutritional, microbial and sensory qualities of fresh cow milk and soy cheeses are as presented in Table 2.

Table 2: Nutritional, microbial and sensory qualities of freeze dried cow milk and soy milk cheeses

\begin{tabular}{ccl}
\hline Qualities & $\begin{array}{c}\text { Freeze Dried Cow } \\
\text { Milk Cheese }\end{array}$ & Freeze Dried Soy Cheese \\
\hline Moisture Content $(\%)$ & $4.28 \pm 0.10$ & $4.19 \pm 0.46$ \\
Ash $(\%)$ & $32.72 \pm 0.12$ & $30.98 \pm 0.55$ \\
Protein $(\%)$ & $32.04 \pm 0.28$ & $34.84 \pm 0.31$ \\
Fat $(\%)$ & $4.05 \pm 0.98$ & $4.30 \pm 0.29$ \\
CHO $(\%)$ & $26.86 \pm 0.90$ & $24.72 \pm 0.01$ \\
$K(M g / 100 g)$ & $6.82 \pm 0.12$ & $6.90 \pm 0.32$ \\
$M g(M g / 100 g)$ & $5.20 \pm 0.40$ & $5.18 \pm 0.60$ \\
Fe $(M g / 100 g)$ & $5.45 \pm 0.03$ & $5.32 \pm 0.11$ \\
Ca $(M g / 100 g)$ & $15.85 \pm 0.03$ & $13.40 \pm 0.35$ \\
Na $($ Mg/lo0g) & $5.20 \pm 0.40$ & $5.40 \pm 0.32$ \\
Bacterial $($ CFU/g) & $2.72 x 10^{3} \pm 0.02$ & $2.54 x 10^{3} \pm 0.03$ \\
Fungi $($ CFU/g) & $2.35 x 10^{6} \pm 0.30$ & $2.38 x 10^{6} \pm 0.50$ \\
Colour & $8.00 \pm 0.02$ & $8.50 \pm 0.01$ \\
Aroma & $8.50 \pm 0.04$ & $7.20 \pm 0.02$ \\
Taste & $8.60 \pm 0.02$ & $8.20 \pm 0.70$ \\
Appearance & $8.50 \pm 0.70$ & $8.50 \pm 0.05$ \\
Overall Acceptability & $8.80 \pm 0.02$ & $9.00 \pm 0.70$
\end{tabular}

The results showed that freeze drying decreases the moisture content of fresh cow milk cheese from $54.02 \%$ to $4.28 \%$ and from $50.89 \%$ to $4.19 \%$ for soy cheese sample. Moisture content is an index of water activity, the high moisture contents of cheese will make it more susceptible to microbial contamination and thus reducing the storage time due to rapid deterioration [23]. Freeze drying is one of the most important methods developed to extend the shelf life of foods and increasing the availability of the nutrients to consumers. 
Freeze drying is known to decrease the water activity of food samples, thus, protecting them against microbial activity and increases the storage life of foodstuffs. The values of water activity ensure the stability of the product against browning, lipid oxidation and enzymatic activity [24].

The results showed that freeze dried cow milk cheese and soy cheese contain $4.28 \%$ and $4.19 \%$ mean moisture respectively, this is similar to previous report by Fonseca et al. [25] who obtained $4.50 \%$ mean moisture for freeze dried cow milk cheese and $4.20 \%$ moisture for soy cheese. The freeze dried cow milk cheese also contain $32.72 \%$ ash, $32.04 \%$ protein and $4.05 \%$ fat while the freeze dried soy cheese contain $30.98 \%$ ash, $34.84 \%$ protein and $4.30 \%$ fat (Table 2 ). The result of the mineral composition of the freeze dried cow milk cheese showed that the value for the sodium, potassium, magnesium, iron and calcium content are $6.82 \mathrm{mg} / 100 \mathrm{~g}, 5.20 \mathrm{mg} / 100 \mathrm{~g}, 5.45 \mathrm{mg} / 100 \mathrm{~g}$, $15.85 \mathrm{mg} / 100 \mathrm{~g}$ and $5.20 \mathrm{mg} / 100 \mathrm{~g}$ respectively. The sodium, potassium, magnesium, iron and calcium content of freeze dried soy cheese are $6.90 \mathrm{mg} / 100 \mathrm{~g}, 5.18 \mathrm{mg} / 100 \mathrm{~g}$, $5.30 \mathrm{mg} / 100 \mathrm{~g}, 13.40 \mathrm{mg} / 100 \mathrm{~g}$ and $5.40 \mathrm{mg} / 100 \mathrm{~g}$ respectively (Table 2 ).

The freeze dried cow milk cheese contains $2.72 \times 10^{3} \mathrm{CFU} / \mathrm{g}$ of bacteria count and $2.35 \times 10^{6} \mathrm{CFU} / \mathrm{g}$ fungi count while freeze dried soy cheese contain $2.54 \times 10^{3} \mathrm{CFU} / \mathrm{g}$ of bacteria count and $2.38 \times 10^{6} \mathrm{CFU} / \mathrm{g}$ fungi count (Table 2). This is comparable to the report on bacterial and fungi count in cheeses which are $2.55 \times 10^{3} \mathrm{CFU} / \mathrm{g}$ and $2.30 \mathrm{x} 10^{6}$ $\mathrm{CFU} / \mathrm{g}$ for freeze dried cow milk cheese and $2.50 \times 10^{3} \mathrm{CFU} / \mathrm{g}$ and $2.32 \times 10^{6} \mathrm{CFU} / \mathrm{g}$ in soy cheese respectively [25]. The freeze dried cow milk cheese and freeze dried soy cheese qualitative properties are 8.00 and 8.50 colour, 8.50 and 7.20 aroma, 8.60 and 8.20 taste, 8.50 and 8.50 appearance, 8.80 and 9.00 overall acceptability respectively (Table 2). Similar result has been reported for dairy products by Lenart [26].

\section{CONCLUSION}

The fresh cow milk and soy milk cheese are rich in protein, ash content, carbohydrate, calcium, potassium, magnesium, iron, quality taste, flavour, appearance, acceptability, with minimal bacteria and fungi count. The carbohydrate, protein, ash content, calcium, sodium, magnesium, taste, appearance, flavour, acceptability increased significantly $(\mathrm{P}<0.05)$ while the moisture content, fat, bacteria and fungi count decreased significantly $(\mathrm{P}<0.05)$ for both the cow milk and soy milk cheeses when freeze dried. The significant decreases in the moisture content as well as the bacteria and fungi counts is an indication of longer storability and extended shelf life of freeze dried cheeses if well packaged in appropriate moisture barrier packaging types. This will in turn solve the problem of deterioration of cheeses and expands its marketability in a portable form.

\section{REFERENCES}

[1] Ramakant, S.J. 2006. The efficacy of nisin can drastically vary when produced in soy cheese in model cheeses. Food Microbiology, 32: 185-190.

[2] Herrington, M.A. 2001. Production of cheese containing probiotic bacteria. Milchwissenschaft. 54: 265-268. 
[3] Akinola, O.J. 2003. The place of the dairy cattle in human diet. A paper presented at a seminar organized by the Department of Animal science. Faculty of Agriculture, Ahmadu Bello University, Zaria.

[4] Andrew, K.O. 2010. Quality evaluation of cow milk, soymilk and cow/soy cheese. Journal of Diary Resources, 9:44-47.

[5] Warsama, V.O., Yadav, D.N., Sharma, G.K and Bawa, A.S. 2006. Nutritional qualities of Nigerian white cheese (wara) Nigerian Veterinary Journal, 6, 82-88.

[6] Igwe, E.C. 2002. The adoption of appropriate technology for dairy processing by Fulani nomads in Nigeria. Journal of Nomadic Studies, 5(3):61-66.

[7] Adetunji, A.O and Babalobi, E.A. 2012. Microbial quality of wara, a southwestern Nigeria soft cheese. Journal of Diary Resources, 24:74-82.

[8] Fabiyi, W.E 2006. Analysis of cheese for histamine, tyramine, histidine, tyrosine and tryptophan. Journal of Diary Science, 68: 2845 - 2846.

[9] Olatunji, E.A. 2012. Low fat white brine cheese made from bivine milk; Chemical Physical, and Sensory attributes. International Dairy Journal, A2: 525 - 540.

[10] Adegoke, F.E., Garcia, E.A., Tomilo, J.M. 2002. Formation of biogenic amines in raw milk. Cheese manufactured with proteinases and different levels of starter culture. Journal of Food Protein, 63: 1551 - 1555.

[11] Brennan, R.A and Day, R.L. 2006. Chemical and physical methods. Standard method for the examination of Dairy products. 15th edition. America Public Health Association, Baltimore, MD. pp: 327 - 404.

[12] Osho, S.R and Dashiell, P.M. 1998. Influenced of pasteurised milk, raw milk and different ripening cultures on biogenic amine concentrations in semi soft cheeses during ripening. European Food Resources Technology, 204: 265 - 272.

[13] Lin,L.R., Vioque,M., Sanchez, E. and Mata, C. 2007. Effect of freeze drying on the sensorial characteristics of a Spanish ewe cheese. Journal of sensorial studies, 2000 (15): $251-262$.

[14] Amano, E.A. 2013. Production of white soft cheese by rennet treatment. Journal of Diary Resources, 43, 112-118.

[15] Adetunji, V.O., Ikheba, S.A., Adedeji, A.M and Alonge, D.O. 2008. Evaluation of the bacteria in milk products sold in Southern Nigeria. Nigeria Veterinary J.24(3), 92-96.

[16] Connor, J.O. 2003. Processing and production of soy cheese; improvement, production and uses. Caldwell, B.E, (Education), American Society for Agronomy; United States America.

[17] Tofu, J.M. 2013. Modern Food Microbiology. 2nd ed. Maryland: Aspen press.

[18] AOAC (Association of Official Analytical Chemists). 2000. Official Methods of Analysis. 15th edition. Washington DC: Association of Official Analytical Chemists.

[19] AACC (American Association of Cereal Chemist). 1999. Approved Methods of the American Association of the Cereal Chemists. Saint Paul, 44-45.

[20] Compendium of Methods for the Microbiological Examination of Food. 2000 Splittstoesser Edition. Washington D.C: 423-431.

[21] Bacteriological Analytical Manual. 2002. Association of Official Analytical Chemist for Washington D.C. 14th Edition. Arlington, 71-76.

[22] Lee, H.S and Castle, W.S. 2007. Seasonal changes of carotenoid pigments and colour in Hamlin, Earlygold and Bundd. Blood orange juices. Journal of Agricultural food chemist, 49(8): 77-82. 
[23] Staperelt, H., Nielsen B.R and Skibsted, H.S. 2007. Effect of heat treatment, water activity and storage temperature and the oxidative stability of dairy products. International Dairy Journal, 7: 331-339.

[24] Margues L.G and Prado M.M, 2011. Ash content of freeze dried tropical fruits. International congress on engineering and food. May 22-26, Athens, Greece, III, 20052006.

[25] Fonseca, L.A., Morgan, O.A and Ampatzoglou, V.B. 2001. Conventional freeze drying of cheese as a preservative technique of cheese. International Diary Journal, 5: 32-38.

[26] Lenart A.A. 2009. Colour changes of freeze dried straw berries osmotically dehydrated before drying. Food Technology operations new vistas. Monograph: 217-223.

\title{
UTICAJ PROCESA LIOFILIZACIJE NA KVALITET SVEŽEG SIRA OD KRAVLJEG I MLEKA SOJE
}

\author{
Tosin Paul ${ }^{1}$, Bolanle Adejumo ${ }^{2}$, Nnaemeka Nwakuba ${ }^{1}$, Augustine Igbozulike ${ }^{1}$ \\ ${ }^{I}$ Department of Agricultural and Bioresources, College of Engineering and \\ Engineering Technology, Michael Okpara University of Agriculture,Umudike, Nigeria. \\ ${ }^{2}$ Department of Agricultural and Bioresources, Federal University of Technology, \\ Minna, Niger State, Nigeria.
}

Sažetak: Istražen je uticaj sušenja primenom procesa liofilizacije, na kvalitet svežeg sira od kravljeg i mleka od soje, sa ciljem da se očuvaju osobine sira u stabilnijem obliku. Uzorci kravljeg i sojinog sira pripremljeni su u svežem stanju sa dimenzijama 2 x $3 \mathrm{~cm} \mathrm{i}$ debljine od $0,2 \mathrm{~cm}$. Kravlji i sojin sir su podeljeni u 6 porcija težine po $100 \mathrm{~g}$. Početne osobine uzoraka sireva određene su korišćenjem dela od $100 \mathrm{~g}$ za svaki uzorak od $500 \mathrm{~g}$ koji su sušeni postupkom smrzavanja.

Hranjivi, mikrobiološki i senzorni kvaliteti zamrznutih sireva određivani su standardnim metodama. Rezultati su pokazali da sveže pripremljeni sir od kravljeg mleka sadrži : $54,02 \%$ vlage, $20,34 \%$ proteina, $6,40 \%$ pepela, $18,11 \%$ masti i $4,25 \%$ ugljenih hidrata, $3,52 \mathrm{mg} / 100 \mathrm{~g}$ natrijuma, 7,02 mg /100 g kalijuma, 5,22 mg /100 g magnezijuma, 6,32 $\mathrm{mg} / 100 \mathrm{~g}$ gvožđa, $11.12 \mathrm{mg} / 100 \mathrm{~g}$ kalcijuma, $3 \times 10^{3} \mathrm{cfu} / \mathrm{g}$ bacterija and $2.54 \mathrm{x} 10^{6} \mathrm{cfu} / \mathrm{g}$ gljivica. Sveže pripremljeni sojin sir sadrži: $50.89 \%$ vlage, $22.05 \%$ proteina, $6.31 \%$ pepela, $19.02 \%$ masti i $4.06 \%$ ugljenih hidrata, 3,52mg / 100g natrijum, $7.04 \mathrm{mg} / 100 \mathrm{~g}$ kalijuma, $5.14 \mathrm{mg} / 100 \mathrm{~g}$ magnezijuma, $6.20 \mathrm{mg} / 100 \mathrm{~g}$ gvožđa, $10.76 \mathrm{mg} / 100 \mathrm{~g}$ kalcijuma, $2.76 \times 10^{3} \mathrm{cfu} / \mathrm{g}$ bacterija and $2.60 \times 10^{6} \mathrm{cfu} / \mathrm{g}$ gljivica. Sadržaj vlage i masti u smrznutom osušenom kravljem i sojinom mleku značajno se smanjio $(\mathrm{P}<0,05)$ sa $54,02 \%$ na 4,28\%, $18,11 \%$ na $4,05 \%$ i $50,89 \%$ na $4,19 \%, 19,02 \%$ na $4,30 \%$. Sušenjem primenom procesa liofilizacije značajno je smanjen sadržaj bakterija i gljivica u svežim sirevima; smanjen je sa vrednosti $3 \times 10^{3} \mathrm{cfu} / \mathrm{g}$ na vrednost $2.72 \times 10^{3} \mathrm{cfu} / \mathrm{g}, 2.54 \times 10^{6} \mathrm{cfu} / \mathrm{g}$, na vrednosti $2.35 \times 10^{6} \mathrm{cfu} / \mathrm{g}$, na vrednost $2.76 \times 10^{3} \mathrm{cfu} / \mathrm{g}$, na vrednost $2.54 \times 10^{3} \mathrm{cfu} / \mathrm{g}, 2.60 \mathrm{x}$ $10^{6} \mathrm{cfu} / \mathrm{g}$, na vrednost $2.38 \times 10^{6} \mathrm{cfu} / \mathrm{g}$ za kravlje mleko i sojin mlečni sir, retrospektivno. 
Sadržaj ugljenih hidrata, proteina, pepela, kalcijuma, natrijuma, magnezijuma, zatim ukus, izgleda, aroma i prihvatljivost sireva od kravljeg mleka značajno se povećava ( $\mathrm{P}$ $<0,05)$ kada se primeni postupak sušenja sa smrzavanjem.

Smanjenje količine vlage, broja masti i mikroba u sirevima povećava stabilnost i rok trajanja sira, ako se on pravilno pakuje.

Ključne reči: Sir, liofilizacija, hranjive osobine, mikrobiološki kvalitet, senzorne osobine.

Prijavljen:

Submitted:

22.01.2020.

Ispravljen:

Revised:

15.05.2020.

Prihvaćen:

Accepted:

18.05.2020 